\title{
The Effect of Project-Based Learning Assisted by Electronic Media on Learning Motivation and Science Process Skills
}

\section{Safaruddin Safaruddin', Nurlaiha Ibrahim ${ }^{2}$, Juhaeni Juhaeni ${ }^{3}$, Harmilawati Harmilawati ${ }^{1}$, Laeli Qadrianti'}

\author{
1 Institut Agama Islam Muhammadiyah Sinjai, Indonesia \\ ${ }^{2}$ Institut Agama Islam Negeri Ambon, Indonesia \\ ${ }^{3}$ Universitas Islam Negeri Sunan Ampel Surabaya, Indonesia
}

\begin{abstract}
This study aims to analyze the effect of using Project Based Learning (PjBL) strategy assisted by Electronic Media in increasing learning motivation and Science Process Skills (KPS) on the material "Heat Transfer". The study used a quasi-experimental pretestposttest experimental design with 59 students. The experimental group was taught using the PjBL strategy while the control group was taught with a conventional strategy that was teacher-centred. Learning motivation is measured using questionnaires distributed to students, and KPS is measured through observation using observation sheets. The results, average score of KPS with the PjBL strategy $=86.33$, the conventional strategy $=74.52$; the average score of learning motivation with PjBL strategy $=78.05$, conventional strategy $=69.49$. Conclude from this data that the use of the PjBL based on e-media strategy is effective and influences the improvement of KPS and learning motivation of elementary school students.
\end{abstract}

Keywords: electronic media; learning motivation; project-based learning; science process skills

Recommended citation: Safaruddin, S., Ibrahim, N., Juhaeni, J., Harmilawati, H., \& Qadrianti, L. (2020). The Effect of Project-Based Learning Assisted by Electronic Media on Learning Motivation and Science Process Skills. Journal of Innovation in Educational and Cultural Research, 1(1), 22-29

\section{INTRODUCTION}

Science learning of elementary school students is still dominated by learning through the media in the form of printed books/student books and companion books with the activity of reading books and completing questions that have been provided in student books or questions contained in companion books, correcting answers, member score and score. These activities are repeated every day, so that makes students tired of learning. Seeing this, learning innovations are needed to increase student learning motivation and science process skills by providing space to be directly involved in constructing their knowledge of heat transfer through simple project activities and occur in everyday life.

One of the innovative learning strategies in 21st century that has delivered success is the Project Based Learning (PjBL) strategy (Bell, 2010), which is student-centred learning with the principle of: contextual, active involvement of students in teaching and learning to achieve learning goals through interaction and knowledge sharing (Kokotsaki et al., 2016). Application of the PjBL strategy in science learning on heat transfer material provides opportunities for students to be directly involved and construct their knowledge. Besides, in the field of science, the PjBL strategy has also been tested for its application. It was expressed by several researchers in the field of curriculum development (Maher, 2004; Gultekin, 2007; Hakim, et al., 2016) in mathematics and accounting (Hsu, et al. 2016; Novarianing, et al., 2017; Gerhana et al., 2017) in the social field (Summers \& Dickinson, 2012; İlhan, 2014) in the field of technology (Eskrootchi \& Oskrochi, 2010). Project-Based learning gives a positive contribution when using real media (Anggreni et al., 2019). Therefore, Wahyuni and Nasbey (2015) and Gerhana, et al. (2017) recommend the use of project-based strategy in learning as well as recent research conducted by Ismuwardani, et al., (2019); Sumarni and Kadarwati, (2020).

In addition to the use of learning strategy, many things influence learning motivation and science process skills for learning. One of them is the innovation of the use of instructional media as a medium for delivering information or material from students to students. Teachers are obliged to innovate following the times and characteristics of the current generation of students (Safitri et al., 2019), which is now known as the $Z$ generation namely generation born around 1995-2010 while children born between 2011-2025 are known as alpha generation (Howe \& Strauss, 2007). Further generation $\mathrm{Z}$ is also famous as the net generation or digital generation where growth and development have a dependency on the use of technology digital (Pratama, 2012). 
Even though the era is already in the digital age, there are still many who rely on intellectuals and printed books as learning resources (Atmojo, 2012). Printed teaching materials are gradually moving now to electronic media such as e-books that can be accessed through a variety of electronic media, both computer and mobile. A movable type of smartphone is a digital media that is almost owned and can be operated by all groups. Apart from being cheaper than a computer or laptop, smartphones are smaller in size, easy to carry everywhere, easy to operate even, and the price is lower for a standard size. The use of mobile becomes an alternative learning media in the digital era (Irwan and Nasution, 2016; Batubara, 2017). The impact of its use in education has been described by several researchers including: can increase student interest and understanding (Irfansyah, 2017), improve science process skills (Nugroho \& Surjono, 2019) increase learning motivation (Law et al., 2010).

Motivation is an element in humans that activates, guides, and maintains individual behaviour or tendencies from time to time which has an important role, both for students and teachers (Sjukur, 2013) Warti, 2018). Motivation, as a psychological process, is influenced by internal factors, namely factors within students such as the desire and expectations for learning, and external factors, namely external factors such as the learning environment (Hidayah \& Hermansyah, 2016). Without motivation, the learning process and outcomes are less than optimal (Hamdu \& Agustina, 2011). Therefore, students' learning motivation is fundamental to foster their will and learning ability (Suprihatin, 2015).

The gap analysis is found after analyzing research results from various journals. Science process skills play a role in helping students to develop minds, participate actively, and build a sense of responsibility in the process of gaining knowledge (Ergul et al., 2011; Atmojo, 2012). Therefore, it needs to be trained and developed in learning science (Suryana et al., 2015). The development of science process skills depends on the strategy and learning media used (Isnaningsih \& Bimo, 2013; Wahyuni et al., 2017; Sumarni \& Kadarwati, 2020). Science process skills include observing, making hypotheses, experimenting, classifying data, sorting data, summarizing and communicating (Wahyuni et al., 2017; Savitri et al., 2017; Ekawati et al., 2018).

The lack of learning motivation and science process skills are caused by the use of monotonous learning strategy, the use of instructional media that rely on student books and companion books and the lack of space to directly involve students in constructing their knowledge, especially related to heat transfer material associated with real life. Based on the analysis of observational data related to low motivation and science process skills in elementary school students, as well as the results of previous research studies related to the use of PjBL strategy, the authors are interested in conducting further research related to the effectiveness of the use of PjBL learning strategy assisted by electronic media towards increasing learning motivation and science process skills in fifthgrade students at Taquma Elementary School in Surabaya.

\section{METHODS}

This research method uses a quasi-experimental research type non-equivalent control group design (Cohen et al., 2011) by providing different treatments between the experimental group and the control group then analyzes the effect of the application and presents a comparison between the use of PjBL learning strategy and conventional learning strategy (Shaughnesy et al., 2012). The determination of the research subject is carried out according to the conditions set at the research site so that it uses a quasi-experimental method, based on the opinion expressed by Setyosari (2013). The research design used is the quasi-experimental design model of the pretest-posttest non-equivalent control group design (Tuckman, 1999; Cohen \& Marrisson, 2011). The design model can be illustrated in Figure 1.

$\begin{array}{llll}\text { Ex } & \mathrm{O} 1 & \mathrm{X} 1 & \mathrm{O} 2 \\ \mathrm{~K} & \mathrm{O} 3 & \mathrm{X} 2 & \mathrm{O4}\end{array}$

Figure 1. the pretest-posttest non equivalent control groups design

$$
\text { Adapted from (Tuckman, 1999) }
$$

Information

\begin{tabular}{|c|c|c|c|c|}
\hline Ex & $=$ Experimental group & $\mathrm{O} 1$ & $=$ & Pretest the experimental group \\
\hline K & $=$ Control group & $\mathrm{O} 2$ & $=$ & test experimental group \\
\hline $\mathrm{X} 1$ & $=$ Application of learning with $\mathrm{PjBI}$ & $\mathrm{O} 3$ & 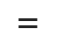 & Pretest of the control group \\
\hline$x 2$ & $=$ Application of non-PjBL learning & 04 & $\begin{array}{l}= \\
=\end{array}$ & $\begin{array}{l}\text { Posttest control group } \\
\text { Intact class group }\end{array}$ \\
\hline
\end{tabular}

Participants

The study was conducted on 59 students in grade 5 at Taquma Elementary School, an experimental group of 29 students and a control group of 30 students. The research subjects were divided into two groups namely: the experimental group with the provision of treatment in the form of using a project-based learning strategy with 
e-media and the control group using the non-project learning strategy namely direct learning. Provision of treatment to the experimental group in the form of project-based learning strategy on heat transfer material as the independent variable while the dependent variable is learning motivation and science process skills.

Instrument

Pretests were given to both groups using instruments that had been tested for validity and reliability. The pretest was given to find out the initial abilities (learning motivation and science process skills) of the two groups. Then, the experimental group was given treatment in the form of a PjBL strategy and a control group with a nonPjBL strategy. A posttest was held for both groups to see the effect of using the PjBL strategy.

Data Collection

Data on student motivation is obtained using a questionnaire instrument containing 30 statements with the choice of SL (Always) with a score of 5, SR (Often) with a score of 4, KK (Sometimes) with a score of 3, JR (Rarely) with a score of 2 and TP (Never) with a score of 1 . The instrument was distributed to students both in the control class and the experimental class. It has been given twice before and after learning took place.

\section{Data Analysis}

Science process skills data were obtained through tests and observations before and at the time of implementation of learning in the experimental class and the control class. Data collection uses science process skills observation sheets which are: observing, making hypotheses, conducting experiments, classifying data, interpreting data, summarizing, and communicating that is equipped with an assessment rubric on each KPS indicator. From the initial ability of the research subjects obtained from the pretest results, an analysis using SPSS to calculate the average score of science process skills with a standard deviation. The data normality test uses the Kolmogorov-Smirnov statistical test at a significant level (a) of 0.05

\section{RESULT AND DISCUSSION}

The results of the study and discussion describe the results of the pretest and posttest, test data normality, differences in Science Process Skills and learning motivation between students taught by using Project Based Learning (PjBL) and non-PjBL strategy, the interaction between KPS and Learning Motivation with PjBL Strategy. The study found Science Process Skill will be stronger if students are asked to learn and do projects. Hall, (2020); $\mathrm{He}$, et al. (2020) Student process skills develop when students are given the freedom to carry out learning activities. Student interest fosters learning motivation which then impacts students' ability to report aspects of process skills.

\section{Description of Pre-test Results of Science Process Skills and Student Motivation}

Pretest results of Science Process Skills and Student Motivation between the control group and the Experiment group recapitulated to get a general picture of the initial conditions of the research subject. The recapitulation of the results of the pretest Science Process Skills and Motivation students are presented in Table 1.

Table 1. Pretest Score Results of Science Process Skills and Student Motivation

\begin{tabular}{lllll}
\hline \multirow{2}{*}{ Group } & \multicolumn{2}{c}{ Skills } & \multicolumn{2}{c}{ Motivation } \\
\cline { 2 - 5 } & Average & Std. Dev & Average & Std. Dev \\
\hline Control & 61,9047 & 6,38574 & 49,5113 & 3,47023 \\
Experiment & 61,3300 & 5,73439 & 51,4945 & 3,01690 \\
\hline
\end{tabular}

Referring to the score of the Science Process Skills pretest and the motivation of the students mentioned above did not show any significant differences in the experimental group or the control group. It gives a picture that the object of research there is no significant difference. From the initial ability of the research subjects obtained from the pretest results, an analysis using SPSS was then carried out to get an idea related to how significant the Science Process Skills were using PjBL and non PjBL learning strategy.

\section{Description of Posttest Results for Science Process Skills and Student Motivation}

Posttest results are student learning outcomes in the form of Science Process Skills, and Student Motivation obtained after learning is given using the PjBL learning strategy. The Posttest scores of Science Process Skills and Motivation of students are presented in the following Table 2. 
Table 2. Results of Post-test Scores for Science Process Skills and Student Motivation Motivation Skills Group

\begin{tabular}{lllll}
\hline \multirow{2}{*}{ Group } & \multicolumn{2}{c}{ Skills } & \multicolumn{2}{c}{ Motivation } \\
\cline { 2 - 5 } & Average & Std. Dev & Average & Std. Dev \\
\hline Control & 74,5247 & 11,59202 & 69,4893 & 2,96831 \\
Experiment & 86,3297 & 4,17073 & 78,0459 & 3,34722 \\
\hline
\end{tabular}

Based on the Table 2, it is known that the group of students who use non-BJPL learning strategy, obtained an average score of Science Process Skills scores of 74.5247 with a standard deviation of 11.59202 and students have Motivation with an average score of 69.44893 and standards deviation 2,96831. While students who use the PjBL learning strategy have an average score of Science Process Skills of 86.3297 with a standard deviation of 4.17073 and students have motivation with an average score of 78.0459 and a standard deviation of 3.34722. Testing requirements analysis is carried out to determine the feasibility of parameterization before hypothesis testing.

\section{Normality Test Data for Science Process Skills and Student Motivation}

The data normality test uses the Kolmogorov-Smirnov statistical test at a significant level (a) of 0.05 . This test aims to determine the normality or symmetry of the score distribution as a unit of analysis, namely the score of Science Process Skills and Student Motivation. The null hypothesis ( $\mathrm{HO})$ in this data normality test states that the sample comes from a normally distributed population. The basis of decision making is if the significance or probability score is less than 0.05 , then the data distribution is concluded to be abnormal, and if the significance or probability score is more than 0.05 , then the data distribution can be concluded normally. The results of calculations using the SPSS program show the results of normality tests of students' Science Process Skills and Motivation are presented in Table 3.

Table 3. Normality Test Results for Science Process Skills and Student Motivation

\begin{tabular}{llcccc}
\hline \multirow{2}{*}{ Group } & \multirow{2}{c}{ Skills } & \multicolumn{3}{c}{ Motivation } \\
\cline { 3 - 6 } & & Kolmogorov Smirnov Z & Prob. & Kolmogorov Smirnov Z & Prob. \\
\hline \multirow{2}{*}{ Control } & Pre & 0,761 & 0,609 & 0,535 & 0,937 \\
& Post & 1,008 & 0,262 & 1,269 & 0,080 \\
\multirow{2}{*}{ Experiment } & Pre & 0,783 & 0,572 & 0,451 & 0,987 \\
& Post & 0,942 & 0,338 & 0,865 & 0,443 \\
\hline
\end{tabular}

Referring to Table 3 of the results of calculating the score of the Kolmogorov-Smirnov Test of Normality it can be concluded that the data of Science Process Skills and Motivation of students in groups of students who learn with non-PjBL learning strategy and those who learn with PjBL learning strategy show a significance score (probability) greater than 0.05 . The meaning is that all Science Process Motivation and Motivation score student data (pretest and posttest) in the experimental class and the control class have a normal distribution so that further testing can be done.

Differences in Science Process Skills between groups of students who implement PjBL learning strategy and students who implement non-PjBL learning strategy. Learning that uses PjBL from research, they are actively involved in making work from the application of concepts from learning outcomes (Cörvers, 2016; Morselli, 2019). To see the difference in PPP as a result of the treatment in the form of using the PjBL strategy, see the following Table 4.

Table 4. T-Test Results for Science Process Skill Scores

\begin{tabular}{|c|c|c|c|c|c|c|c|}
\hline & & \multicolumn{2}{|c|}{$\begin{array}{c}\text { Levene's Test for Equality } \\
\text { of Variances }\end{array}$} & \multicolumn{4}{|c|}{ t-test for Equality of Means } \\
\hline & & $\mathrm{F}$ & Sig. & $\mathrm{t}$ & df & Sig. (2-tailed) & Mean Difference \\
\hline \multirow{2}{*}{ KSP } & $\begin{array}{c}\text { Equal variances } \\
\text { assumed }\end{array}$ & 42,041 & 0,000 & $-5,169$ & 57 & 0,000 & $-11,80499$ \\
\hline & $\begin{array}{l}\text { Equal variances } \\
\text { not assumed }\end{array}$ & & & $-5,238$ & 36,607 & 0,000 & $-11,80499$ \\
\hline
\end{tabular}

From the output of the SPSS Independent Samples Test results show that the Sig Lavene's Test scores 0,000 . This score is smaller than 0.05 , from the data it can be concluded that there is a difference in the score of 
the Science Process Skill scores between groups using PjBL and non PjBL learning strategy so that testing can be carried out using independent t-test with the assumption that the variety of data is not homogeneous (equal variance not assumed). From Table 4 shows, the score of the independent t-test for Science Process Skills between groups using learning strategy PjBL e-media and non-PjBL obtained significance scores of $0,000(p<0.05$ reject $\mathrm{Ho}$ ), which means there are differences that meaningful in both strategy used. It is also reinforced by seeing the average score of posttest Science Process Skills in two groups of students, that the average score of posttest Science Process Skills groups of students who learn using PjBL learning strategy 11,80499 is higher than the average score of students in learning groups with non PjBL learning strategy. Thus, it can be concluded that in general, the score of Science Process Skills of students who learn with PjBL learning strategy is better than groups of students who study with non PjBL learning strategy. It means that the PjBL learning strategy is effective in improving students' Science Process Skills. It reinforces the previous finding that PjBL is student-centred learning that provides meaningful learning experiences (Afriana et al., 2016) and is effective in increasing literacy for students (Eliana et al., 2016).

Differences in student motivation between groups of students who implement PjBL learning strategy and students who implement non-PjBL learning strategy.

Table 5. T-Test Results for Student Motivation Scores

\begin{tabular}{cccccccc}
\hline & \multicolumn{3}{c}{$\begin{array}{c}\text { Levene's Test for Equality } \\
\text { of Variances }\end{array}$} & \multicolumn{4}{c}{ t-test for Equality of Means } \\
\hline & $\mathrm{F}$ & Sig. & $\mathrm{t}$ & $\mathrm{df}$ & Sig. (2-tailed) & Mean Difference \\
\hline \multirow{3}{*}{ Motivation } & $\begin{array}{c}\text { Equal variances } \\
\text { assumed } \\
\begin{array}{c}\text { Equal variances } \\
\text { not assumed }\end{array}\end{array}$ & 0,577 & 0,451 & $-10,397$ & 57 & 0,000 & $-8,55653$ \\
\hline
\end{tabular}

From the output of the SPSS Independent Samples Test results show that the Sig Lavene's Test score obtained 0.451 . The score is higher than 0.05 , from the data it can be concluded that there is no difference in the diversity of students' motivational scores between groups using PjBL and non PjBL learning strategy so that testing can be carried out using independent t-test with equal variance assumed. From Table 5 shows the score of independent t-test for student motivation between groups using PjBL and non PjBL learning strategy obtained significance score of $0,000(p<0.05$ starting Ho), which means that there are significant differences in the two strategies used. It is also reinforced by seeing the average posttest score of students' motivation in two groups of students, that the average posttest score of students' motivation in groups of students learning to use the PjBL learning strategy 8.55653 is higher than the average score of groups of students studying with non PjBL learning strategy. Thus, it can be concluded that in general, the motivation scores of students who learn with PjBL learning strategy are better than groups of students who study with non PjBL learning strategy. It means that the PjBL learning strategy is effective in increasing student motivation.

The influence of the use of PjBL learning strategy assisted by e-media on Science Process Skills and Student Motivation. A multivariate test of the Hotelling's Trace type is done to see the effect of using the PjBL strategy on Science Process Skills and Student Motivation, in Table 6.

Table 6. Results of Multivariate Tests Analysis

\begin{tabular}{ccccr}
\hline Hotelling's Trace Value & $F$ & \multicolumn{1}{c}{ Hypothesis dfError df Sig. } \\
\hline Intercept & $565,84815843,741$ & 2,000 & $56,0000,000$ \\
Test & 1,951 & 54,641 & 2,000 & $56,0000,000$ \\
\hline
\end{tabular}

Based on the results of testing with Hotelling's Trace showed a significant number of 0,000 and smaller than alpha 0.05, ( $p<0.05)$. Thus, Ho is rejected, and it can be concluded that the posttest scores of Science Process Skills and Student Motivation together show significant differences in the two learning strategies (PjBL and non$\mathrm{PjBL})$. Where based on the average posttest scores of Science Process Skills and Motivation of students with the PjBL learning strategy shows the average score is higher than the score of the posttest of Science Process Skills and Motivation of students with learning strategy no PjBL. Comparison of the average score of the posttest Science Process Skills and Student Motivation on both learning strategy ( $\mathrm{PjBL}$ and non-PjBL) can be presented in the form of Figure 1. 


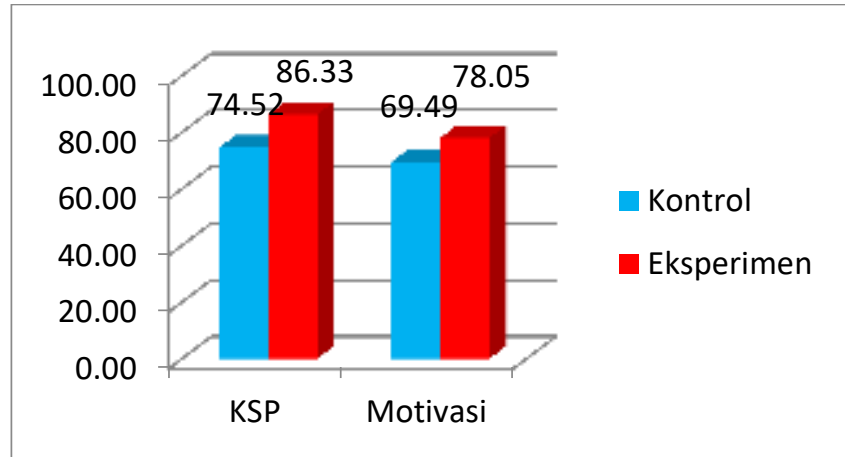

Figure 1. Comparison of the mean scores of the posttest of Science Process Skills and Student Motivation on both learning strategies (PjBL and non-PjBL)

Based on the Figure 1, it can be seen that the average score of the posttest of Science Process Skills and Student Motivation with the PjBL learning strategy shows the average score that is higher than the score of the posttest of Science Process Skills and Motivation of students with non-PjBL learning strategy.

\section{CONCLUSION}

The use of Project-Based Learning (PjBL) strategy effectively improves Science Process Skills (KPS). It can be seen from the average KPS results using the PjBL strategy $=83.33$, the conventional strategy $=74.52$. Likewise, with the increase in student motivation, students who are taught using the PjBL strategy have an average score of learning motivation that is better than students taught with conventional learning strategy, the average score of learning motivation with the PjBL strategy $=78.08$, conventional strategy $=69.49$. Based on these data, it can be concluded that the use of the PjBL strategy affects improving science process skills as well as increasing elementary school student learning motivation.

\section{REFERENCES}

Afriana, J., Permanasari, A., \& Fitriani, A. (2016). Project based learning integrated to stem to enhance elementary school's students scientific literacy. Jurnal Pendidikan IPA Indonesia, 5(2), 261-267.

Anggreni, Y. D., Festiyed, \& Asrizal. (2019). Meta-Analisis Pengaruh Model Pembelajaran Project Based Learning Terhadap Kemampuan Berfikir Kritis Peserta Didik SMA. Pillar of Physics Educatioan, 12(4), 881-888.

Atmojo, S. E. (2012). Profil keterampilan proses sains dan apresiasi siswa terhadap profesi pengrajin tempe dalam pembelajaran ipa berpendekatan etnosains. Jurnal Pendidikan IPA Indonesia, 1(2), 115-122.

Batubara, H. H. (2017). Pengembangan Media Pembelajaran Matematika berbasis Android untuk Siswa SD/MI. Muallimuna : Jurnal Madrasah Ibtidaiyah, 3(1), 12.

Bell, S. (2010). Project-Based Learning for the 21st Century: Skills for the Future. The Clearing House: A Journal of Educational Strategies, Issues and Ideas, 83(2), 39-43.

Cohen, L. ., \& Marrisson, K. (2011). Research Methods In Education. Routledge Taylor \& Francis Group.

Cohen, L., Manion, L., \& Marrison, K. (2011). Research Method and Education. Routledge.

Cörvers, R., Wiek, A., de Kraker, J., Lang, D. J., \& Martens, P. (2016). Problem-based and project-based learning for sustainable development. In Sustainability Science (pp. 349-358). Springer, Dordrecht.

Ekawati, N. W., Iswari, R. S., \& Lisdiana. (2018). The influence of scientific independence towards students' content analysis and science process skills on cell metabolism topic. Jurnal Pendidikan IPA Indonesia, 7(4), 420-427.

Eliana, E. D. S., Senam, Wilujeng, I., \& Jumadi. (2016). The effectiveness of project-based e-learning to improve ICT literacy. Jurnal Pendidikan IPA Indonesia, 5(1), 51-55.

Eskrootchi, R., \& Oskrochi, G. R. (2010). A Study of the Efficacy of Project-based Learning Integrated with Computer-based Simulation - STELLA Project-based learning. 13, 236-245. 
Ergül, R., Şımşeklı, Y., Çaliş, S., Özdılek, Z., Göçmençelebı, Ş., \& Şanli, M. (2011). The Effects Of Inquiry-Based Science Teaching On Elementary School Students' Science Process Skills And Science Attitudes. Bulgarian Journal of Science and Education Policy (BJSEP), 5(1), 48-69.

Gerhana, M. T. C., Mardiyana, M., \& Pramudya, I. (2017). The Effectiveness of Project Based Learning in Trigonometry. Journal of Physics: Conference Series, 895(1).

Gultekin, M. (2007). The Effect of Project Based Learning on Learning Outcomes in the Fifth-Grade Science Education. Ilköğretim-Online, 6(1), 93-112.

Hakim, A., Setyosari, P., Degeng, I. N. S., \& Kuswandi, D. (2016). Pengaruh Strategi Pembelajaran dan Motivasi Belajar Terhadap Pemahaman Konsep dan Keterampilan Motorik. JinoTEP, 3.

Hall, K. L., Vogel, A. L., \& Croyle, R. T. (2020). Correction to: Strategies for Team Science Success. In Strategies for Team Science Success (pp. C1-C1). Springer, Cham.

Hamdu, G., \& Agustina, L. (2011). Pengaruh Moivasi Belajar Siswa Terhadap Prestasi Belajar IPA di Sekolah Dasar (Studi Kasus terhadap Siswa Kelas IV SDN Tarumanagara Kecamatan Tawang Kota Tasikmalaya). Jurnal Penelitian Pendidikan, 12(1), 81-86.

He, J., Philip, S. Y., Shi, Y., Li, X., Xie, Z., Huang, G., ... \& Xiao, F. (2020). Correction to: Data Science. In International Conference on Data Service (pp. C1-C1). Springer, Singapore.

Hidayah, N., \& Hermansyah, F. (2016). Hubungan Antara Motivasi Belajar dan Kemampun Membaca Pemahaman Siswa Kelas V Madrasah Ibtidaiyah Negeri 2 Bandar Lampung Tahun 2016/2017. Terampil: Jurnal Pendidikan Dan Pembelajaran Dasar, 3(2), 87-93.

Howe, N., \& Strauss, W. (2007). The Next 20 Years: How Customer and Workforce Attitudes Will Evolve. Harvard Business Review.

Hsu, C., Yen, S., \& Lai, W. (2016). The Effect of Problem-Based Learning on Learning Outcomes of Accounting Students. Asian Journal of Finance \& Accounting, 8(2), 135.

ilhan, I. (2014). A study on the efficacy of project-based learning approach on Social Studies Education: Conceptual achievement and academic motivation. Educational Research and Reviews, 9(15), 487-497.

Irfansyah, J. (2017). Media Pembelajaran Pengenalan Hewan Untuk Siswa Sekolah Dasar Menggunakan Augmented Reality Berbasis Android. Journal of Information Engineering and Educational Technology, 1(1), 9.

Irwan, M., \& Nasution, P. (2016). Strategi Pembelajaran Efektif Berbasis Mobile Learning Pada Sekolah Dasar. 10(1), $1-14$.

Ismuwardani, Z., Nuryatin, A., \& Doyin, M. (2019). Implementation of Project Based Learning Model to Increased Creativity and Self-Reliance of Students on Poetry Writing Skills. 8(40), 51-58.

Isnaningsih, A., \& Bimo, D. S. (2013). Penerapan lembar kegiatan siswa (LKS) discovery berorientasi keterampilan proses sains untuk meningkatkan hasil belajar IPA. Jurnal Pendidikan IPA Indonesia, 2(2), 136141.

Kokotsaki, D., Menzies, V., \& Wiggins, A. (2016). Project-based learning: A review of the literature. Improving Schools, 19(3), 267-277.

Law, K. M. Y., Lee, V. C. S., \& Yu, Y. T. (2010). Learning motivation in e-learning facilitated computer programming courses. Computers \& Education, 55(1), 218-228.

Maher, A. (2004). Learning Outcomes in Higher Education: Implications for Curriculum Design and Student Learning. The Journal of Hospitality Leisure Sport and Tourism, 3(2), 46-54.

Morselli, D. (2019). Reflecting on the Expansive Learning Process. In The Change Laboratory for Teacher Training in Entrepreneurship Education (pp. 111-124). Springer, Cham. 
Novarianing, A. D., Setyosari, P., Hitipeuw, I., \& Chusniyah, T. (2017). The Influence of Project-based Learning Strategy and Self-regulated Learning on Academic Procrastination of Junior High School Students' Mathematics Learning. American Journal of Educational Research, 5(1), 88-96.

Nugroho, T. A. T., \& Surjono, H. D. (2019). The effectiveness of mobile-based interactive learning multimedia in science process skills. Journal of Physics: Conference Series, 1157(2), 1-6.

Pratama, H. C. (2012). Cyber Smart Parenting. Visi Anugerah Indonesia.

Safitri, D., Sujarwo, \& Putra, Z. F. F. (2019). Pemberdayan Kelompok Guru Dalam Membuat Media Pembelajaran Quizizz. Prosiding Pengabdian, 1(1), 1-6.

Savitri, E. N., Wusqo, I. U., Ardhi, M. W., \& Putra, P. D. (2017). Enhancement of science students' process skills through implementation of green learning method (GeLeM) with conservation-based inquiry approach. Jurnal Pendidikan IPA Indonesia, 6(2), 237-244.

Setyosari, P. (2013). Metode Penelitian Pendidikan dan Pengembangan. Prenadamedia Group.

Shaughnesy, J., J., Zechmeister, EugeneB., Zechmeister, \& S., J. (2012). Research Methods In Psychology (Ninth Edi). McGraw-Hill.

Sjukur, S. B. (2013). Pengaruh blended learning terhadap motivasi belajar dan hasil belajar siswa di tingkat SMK. Jurnal Pendidikan Vokasi, 2(3), 368-378.

Sumarni, W., \& Kadarwati, S. (2020). Ethno-STEM Project Based Learning : ITS Impact to Critical and Creative Thinking Skills. Jurnal Pendidikan IPA Indonesia, 9(1), 11-21.

Summers, E. J., \& Dickinson, G. (2012). A Longitudinal Investigation of Project - based Instruction and Student Achievement in High School Social Studies. Interdisciplinary Journal of Problem-Based Learning, 6(1), 82103.

Suprihatin, S. (2015). Upaya Guru Dalam Meningkatkan Motivasi Belajar Siswa. PROMOSI (Jurnal Pendidikan Ekonomi), 3(1), 73-82.

Suryana, A., Binadja, A., \& Sulistyorini, S. (2015). Pengembangan Instrumen Performance Assessment Praktikum Bervisi SETS untuk Mengukur Keteampilan Proses Sains. Journal of Primary Education, 4(1), 1-9.

Tuckman, B. W. (1999). Conducting Educational Research. Harcout Brace Jovanovich Publisher.

Wahyuni, C., \& Nasbey, H. (2015). Improvement of Learning Process and Learning Outcomes in Physics Learning by using Collaborative Learning Model of Group Investigation at High School (grade X, SMAN 14 Jakarta). Journal of Education and Practice, 6(11), 75-80.

Wahyuni, S., Indrawati, I., Sudarti, S., \& Suana, W. (2017). Developing science process skills and problemsolving abilities based on outdoor learning in junior high school. Jurnal Pendidikan IPA Indonesia, 6(1), 165-169.

Warti, E. (2018). Pengaruh Motivasi Belajar Siswa terhadap Hasil Belajar Matematika Siswa di SD Angkasa 10 Halim Perdana Kusuma Jakarta Timur. Mosharafa: Jurnal Pendidikan Matematika, 5(2), 177-185. 